\title{
THE PECULIARITIES OF STATE MANAGEMENT OF BANKS CAPITALIZATION IN UKRAINE
}

\author{
Yuriy RADELYTSKYY ${ }^{1}$, Yuliya POPIVNYAK², Zoryana TENYUKH ${ }^{3}$
}

Ivan Franko National University of Lviv, Ukraine

\begin{abstract}
Research subject. The subject in this article is theoretical, methodical and applied aspects of state management of banks' capitalization in Ukraine, a consideration which allows the estimate efficiency of Ukrainian banks refinancing and recapitalization, as well as to enunciate practical recommendations concerning an increase of their capitalization level. The purpose is an analysis of government support measures for the domestic bank system; furthermore the search for additional sources of financing bank funds and the development of capitalization level increase in conditions of social and economic transformations. Methodology. In the research there are used general scientific methods of learning economic facts and the use of processes in their steady development and correlation: logic analysis, methods of scientific abstraction, induction, deduction, optimization, grouping and comparison, as well as graphic and tabular methods. Results. The questions of government control in the bank system in the period of the world financial crisis is researched on international level by the Financial Stability Council, Basel Committee on Banking Supervision, specialists of the World Bank and International Monetary Fund. As a result of relative novelty of these problems only a small number of researches is devoted to the use of government bank support instruments and therefore further development of this topic has practical value for improving the renewal mechanisms of financial stability and reliability of the bank system in Ukraine. After the analysis of the government control measures of the domestic bank capitalization, since 2009 , and the effectiveness of budget resources segregation on refinancing and recapitalization of bank institutions in Ukraine (including crisis period), it was found out that these mechanisms, unfortunately, did not change much the situation on the bank market. Taking into account the unstable political situation in Ukraine and its military conflict with Russia, which has influenced the inflation growth, depreciation of the national currency and panic outflow of deposits, furthermore the forecast of an intensified bank crisis is used as confirmation to the problems with liquidity and bankruptcy of numerous groups of the domestic banks. Therefore advisable is working of a structural and logical scheme of banks' capitalization level increase, which consists of a selection of four categories of banks after stress-testing the measures of obligatory capitalization or processes of amalgamation and merging: financially consistent and reliable; 2) problem; 3 ) insolvent; 4) bad (helpless) banks. Conclusions. Realization of problem banks' recapitalization with participation of the government is one of the possible variants of initiatives in handling the economic crisis' condi-tions. Nevertheless, problems with deposit-returns and debt-discharges are better to solve by refinancing and restricting their liabilities than by recapitalization. In authors' opinion, more reasonable methods of banks' additional capitalization-financing is attracting resources from privatization of state property and introduces new activation mechanisms of citizens savings used, particularly for converting deposits of artificial and physical bodies in hryvni and dollars into the preference shares of domestic banks.
\end{abstract}

Key words: bank, bank capital, capitalization level, recapitalization, refinancing, National Bank of Ukraine, preference shares.

JEL Classification: G21, G28, G32, G33, G38

\footnotetext{
Corresponding author:

${ }^{1}$ Department of Accounting and Audit, Ivan Franko National University of Lviv.

E-mail: 05051@ukr.net

${ }^{2}$ Department of Accounting and Audit, Ivan Franko National University of Lviv.

E-mail: bylja@ukr.net

${ }^{3}$ Department of Accounting and Audit, Ivan Franko National University of Lviv.

E-mail: tenyukh.zoryana@gmail.com
} 


\section{1. Вступмение}

Мировой финансовый кризис выявил высокую концентрацию рисков и существенные Аисбалансы в банковской системе как Украины, так и других стран. Из бюАжетов были выделены значительные суммы среАств на возобновление стабильности банковских систем, а также реформирования системы регулирования и наАзора Аля нейтрализации вероятных проблем в будущем. ПровеАённые мероприятия по рекапитализации системных финансовых учреждений за счет бюАжетных среАств привели к увеличению Аоли государственного капитала, которое наблюдается впервые за многие годы миберализации и поощрения частной собственности. ОАнако в настоящее время процессы капитализации банков происходят меАленнее, чем этого требуют тенденции развития межАународного рынка капитама и приходиться констатировать весьма низкий уровень капитализации банковской системы Украины. Более того, современные международные требования регулирования банковской Аеятельности к капиталу и Аиквидности (Базель III) предусматривают повышение общего уровня капитамизации, качества и структуры капитала банков с целью покрытия рисков банковской Аеятельности, введение которых явмяется необхоАимым Аля стабильного функционирования финансового рынка Украины в условиях глобализации. Важным явмяется также вопрос выхода государства из уставного капитала отечественных банков как временного, а не Аолгосрочного антикризисного Аействия, и поиск способов финансирования Аокапитализации банков. Учитывая это, процессы адекватного наращивания объема, оптимизации структуры и совершенствования управления капиталом банков приобреки особенную актуацьность.

Цемью статьи явмяется анализ мероприятий госуАарственной поААержки отечественной банковской системы, а также поиск Аополнительных источников финансирования капитала банков и разработка схемы повышения уровня капитализации банков в условиях социально-экономических трансформаций. В соответствии с определенной целью поставлены такие задания: раскрыть мероприятия государственного управления капитализацией отечественных банков; проанализировать процессы рефинансирования и рекапитализации банковских учреждений в Украине; Аать оценку эффективности рекапитализации отечественных банков в условиях кризиса; преАможить практические рекоменАации относительно повышения уровня капитализации банков в Украине.

В работе использованы общенаучные методы познания экономических явлений и процессов в непрерывном их развитии и взаимосвязи. Во время решения заданий, поставленных в статье, применены методы могического анализа (при опреАелении проблем и путей повышения уровня капитализации банков); научной абстракции, индукции, АеАукции (в исследовании капитализации банка как экономической категории); оптимизации (в процессе разработки оптимизационной модели уровня капитализации банков); группировки и сравнения (во время обобщения отчетной информации исследуемых банковских учрежАений); синтеза, графического и табличного метода (Аля нагляАного отражения результатов проведенного исслеАования).

\section{2. Анамиз послеАних публикаций}

В научной митературе проблематика низкого уровня капитализации банков исследуется в труАах таких известных ученых, как М. А. Алексеенко, 3. М. Васильченко, А. П. Вожжов, І. Б. Ивасив, В. В. Коваценко, А. М. Мороз, С. М. Савцук, О. О. Чуб. СреАи русских исслеАователей отмеченной проблеме посвящены труды В. В. Иванова, В. В. Клюевой, В. И. Колесникова, А. М. Косого, В. О. Пцотникова, К. О. Попова, М. В. Романовского, С. О. Селищева, О. Ю. Симановского, Б. И. Соколова, В. А. Царькова, Ю. М. ЮАенкова. Фундаментальными в этой проблематике явмяются исследования западных ученых А. Бегера, Є. Бригхема, Ч. Вулфена, Р. Г. Габбарта, П. Роуза, Т. У. Коха, Ф. Мышкина, Аж. Ф.Синки, $\Lambda$. Мауэра и Аругих. Вопросы относительно межАународных стандартов достаточности капитала банка, которые способствуют адекватной капитамизации отдельных банков и банковской системы в целом, нашии отражение в трудах таких ученых, как У. Гаумерт, П. М. Нагь, У. Шумьте-Маттлер, К. Рамонас, Аж. Уотсон, Аж. Хоук, а также В. В. Салтинский, К. О. Киреева, К. Ф. Черкашина, Н. Р. Сапожник. Исследованию вопросов государственного регумирования капитализации банковских учрежАений УАемяют внимание многие ученые: О. Барановский, В. Геец, О. Азюблюк, Г. Карчева, В. Козюк, В. Крылов, О. Ааврушин, В. Мищенко, С. Науменкова, К. Олексенко, С. Циганов, В. Шелудько.

Невзирая на многочисленные исследования ученых, в условиях продолжения неблагоприятных макроэкономических трендов на фоне социально-политического напряжения в стране, заметим, что не все аспекты Аанной проблемы в Аостаточной мере раскрыты, в частности это касается отсутствия еАиного подхода к определению сущности уровня капитализации банков и системного исследования ее механизма; вопросов разработки аггрегированной системы индикаторов оценки капитала банков, которая бы давала возможность обнаруживать трудности на ранних стадиях их возникновения Аля избежания проблем с миквиАностью и пиатежеспособностью и, соответственно, избыточных рефинансирований, направленных на погашение обязательств банковских учрежАений; реформирования отечественного банковского регулирования в контексте ввода межАународных стандартов 
банковского надзора в условиях глобализации, а также присутствия государственного капитала в банковской системе Украины и его вывода из нее, поиск альтернативных источников докапитализации отечественных банков. В условиях усиления процессов интеграции и глобализации экономических отношений в Аетальном исследовании и освещении нужАается усовершенствование работы по государственному управлению Аостаточностью капитала банков.

\section{3. Результаты исследования}

В отечественных банках проблемы с недостаточностью капитаца начацись в 2008 г. По оценкам экспертов, к началу в 2009 г. ведущие банки нуждались в капитале размером около 22 мирА. грн. Отметим, что капитац банка должен быть адекватным объемам Аепозитного портфеля, веАь его величина свиАетельствует о надежности возвращения привлеченных Аепозитов. ОАнако соотношение уставного капитала и Аепозитной базы банков Украины не было рациональным. В частности, уставный капитац банка «Надра» в январе 2009 г. составлял 38,7 млн. евро, а Аепозитный портфель физических миц 800 млн евро. Соответствующие показатели «РодовиА Банка» Аостигли 43 млн. евро и 278 млн. евро соответственно (Kudriashov, 2010).

Первый этап антикризисных Аействий предусматривац рефинансирование банковских учрежАений на сумму около 36,94 мирА. грн. В конце 2008 г. наибольшую госуАарственную поААержку получили такие банки: ОАО «НаАра», ОАО «Проминвестбанк», ОАО «КБ «Приватбанк», АО «Банк «Финансы и креАит», ОАО «КБ «Финансовая инициатива» и некоторые Аругие, а также ОАО «ОщаАбанк», ОАО «РодовиА Банк» (National Bank of Ukraine, 2016).

Государство провело рефинансирование учреждений без четкого соблюдения стандартов прозрачности, равенства Аоступа всех банков, операционной независимости, наличия залогового обеспечения и низкого уровня риска. Некоторые из рефинансируемых банков уже через год заявили о недостатке капитала. Хотя на международном уровне принята практика, согласно которой банк, который имеет проблемы платежеспособности, Аолжен сначала решить вопрос нехватки капитала и только потом претендовать на выдемение новых кредитных ресурсов от центрального банка.

В связи с УхуАшением состояния АиквиАности и с целью реализации валютной политики проводились аукционы по продаже валюты по мьготному курсу Аля заемщиков, что Аало возможность погасить часть займов в иностранной валюте. В конце 2008 г. быи установлен мораторий на Аосрочное снятие Аепозитов и кредитование, что способствовало ограничению оттока средств из банковской системы Украины.
Национальный банк Украины (НБУ) вводил временные аАминистрации в банках, которые столкнулись с острой проблемой платежеспособности.

СреАи антикризисных мероприятий регумяторов банковской системы Украины необходимо отметить принятие Закона Украины «О первоочередных мерах относительно предотвращения негативных послеАствий финансового кризиса и о внесении изменений к некоторым законодательным актам Украины» от 31.10.2008 г. № 639 - VI, основным положением которого стало созАание Стабилизационного фонда. Целью Аеятельности такого фонда является направление государственных расходов на стимулирование внутреннего спроса на отечественном рынке. К сожамению, из-за фактического отсутствия бюАжетных среАств этот шаг носил сугубо Аекларативный характер. Кроме того, государству в мице Министерства финансов Украины было предоставлено право принимать участие в формировании и/или увеличении уставных капиталов банков (капитализации банков) путем приобретения акций первичной эмиссии (Аолей в уставном капитале) банков или акций Аополнительной эмиссии (Аополнительных вкладов) банков в обмен на государственные облигации Украины и/или покупки этих акций за средства государственного бюджета Украины.

Также было увеличено до 150 тыс. грн., а впослеАствии и Ао 200 тыс. грн., гарантированную сумму возмещения среАств физических миц по Аепозитам в размере вклала, включая проценты, которые подлежат выплате Фондом гарантирования вкладов физических миц в скучае отозвания банковской мицензии и инициирования процеАуры миквидации банка (Deposit Guarantee Fund, 2016).

Второй этап характеризовался рекапитализацией отечественных банков. Исследователи МВФ отмечают, что расходы на рекапитализацию и Аругие меры по реструктуризации на протяжении 20072011 гг. Аостигли 4,5\% от ВВП (Tsyhanov, 2014). Государство не только стимулировало банки провоАить рекапитализацию, но и стало непосредственным участником процесса, национахизировав самые проблемные банки.

В начаме 2009 г. было объявлено, что правительство начнет рекапитализацию 10-15 наибольших банков с цемью их озАоровления за счет среАств госуАарственного бюджета. Рекапитализация должна была осуществляться путем выкупа не менее как 50\% пиюс одна акция. На финансирование этой программы из государственного бюджета предусматривалось выделить 44 млрА. грн. (или приблизительно 2-3\% ВВП). Заявмения на рекапитализацию пришки от нескольких банков, в частности «НаАра» (потребность в капитале около 5 мирА. грн.), «Укрпромбанк» (7 мирА. грн.), «Укргазбанк» (1,5 мирА. грн.), «Финансы и кредит» (более 2 мирА. грн.), «РодовиА Банк» (3,2 мирА. грн.). 
Отбор банков Амя оздоровмения за счет государственных среАств проводился по определенным критериям, которые касаются объемов депозитов насемения и доли активов банка в совокупных активах всей банковской системы Украины. Было принято решение, что банки, которые нужАаются в государственной подАержке, Аолжны отвечать таким требованиям: сумма депозитов населения в банке Аолжна составмять более чем $1 \%$ Аепозитов всей банковской системы или активы - более чем $2 \%$ суммы активов банковской системы.

Несмотря на то, что увеличение уставного капитала при наличии убытков нецелесообразно, веАь в таком случае средства будут направлены на погашение обязательств, а не на обеспечение прибыльной работы учреждения, следовательно, при таких условиях и государственные ресурсы, привлеченные с целью рекапитализации, будут направмяться на погашение Аолга, специалисты МВФ и Всемирного банка подАержали государственную программу рекапитамизации банков в Украине, поскольку считали, что в условиях финансового кризиса поступления капитала от их владельцев и новых инвесторов стало проблематичным. По мнению экспертов, государство Аолжно поААержать пополнение капитала в проблемных банках, имеющих системное значение.

Резкий отток Аепозитов, а также значительные ограничения на привлечение ресурсов путем эмиссий акций и размещения Аолговых ценных бумаг могут стать причиной ухудшения положения не только отдельных банков, но и финансово-кредитной системы в целом. СлеАствием будет ограничение проведения активных операций, которое приведет к уменьшению креАитования экономики, совокупного спроса и усилению кризисных явлений в реальном секторе. При таких условиях государство не может не вмешиваться в решение вопроса оздоровления банковской системы. При этом оно Аолжно стать главным акционером и осуществцять полный корпоративный контроль Аля обеспечения защиты собственных интересов. Такой вариант рассматривался как наименее затратный Аля укрепления банковской системы Украины. В то же время подчеркивалось, что позитивных результатов можно Аостичь, когАа вложенные средства будут использованы по целевому назначению (Аля удовлетворения претензий вклаАчиков и обеспечения креАиторов банков). Не искАючалось, что владельцы банков могут потерять часть ими Ааже все свои инвестиции. После стабилизации финансового состояния банков РуковоАство АОлжно обеспечить максимальное увеличение стоимости активов банка и подготовить его к продаже частным собственникам.

Таким образом, иностранные эксперты в качестве основной цели рекапитализации проблемных банков с использованием государственных ресурсов преАмагали решение проблем с погашением обязательств
переА вкладчиками и креАиторами. Такой подход был принят правительством. В частности, специалисты Министерства финансов Украины придерживались мысли, что безусловной идеей рекапитализации явмяется обеспечение полного Аоступа гражАан к Аепозитам.

По оценке В. Пинзеника, с учетом 44 мирА. грн., которые было предусмотрено направить на рекапитализацию коммерческих банков, реальный дефицит государственного бюджета Украины в II квартале 2009 г. стал значительно больше, чем задекларированный, и превысии 10\% ВВП. Аля его погашения правительство осуществляет эмиссию облигаций внутреннего государственного займа. Отсутствие Аостаточного объема бюАжетных ресурсов Аля рекапитализации банков заставило обратиться к привлечению креАитов МВФ. ПреАыдущий транш был предоставлен Аля провеАения рефинансирования проблемных банков. ОАнако его использование оказалось нерациональным, ведь банки направили полученные среАства иностранным кредиторам, а вклаАчикам-резидентам возвращать депозиты не спешили. Следовательно, большие трудности у государства возникают с проведением рефинансирования банков, веАь вложение капитала в уставные фонды преАусматривает принятие на себя долгов банка, то есть частные Аолги превращаются в государственные. Необходимо также учесть, что проведение рекапитализации банков со стороны правительства может сопровожАаться коррупцией.

Необходимо обратить внимание на то, что переАача полного или контрольного пакета акций госуАарству может привести к снижению качества корпоративного управления в результате Аоминирования государственных органов в провеАении контроля за Аеятельностью менеАжеров. При таких условиях деятельность менеАжмента не столько определяется рыночными факторами, сколько зависит от решений политиков, которые имеют отношение к корпоративному контролю, то есть происходят Аостаточно существенные изменения в мотивации их деятельности. Работа менеАжмента может быть нацелена прежАе всего на выполнение установок органов государственного управления, которые нереАко направлены на решение текущих, а не будущих проблем. В то же время вместо углубления рыночных преобразований наблюдается усимение административного вмешательства в экономику.

Кроме того, в условиях перехода контрольных пакетов акций в собственность государства усложняются также операции банка по Аальнейшему увеличению уставного капитала путем проведения дополнительных эмиссий и размещения ценных бумаг среди частных собственников. Попытки получить полный контроль за деятельностью банка со стороны правительства, постоянные проблемы по преАоставлению бюАжетных среАств на приобретение пакетов акций 
Аополнительной эмиссии тормозят проведение операции по увеличению капитализации банковского учрежАения. Такой корпоративный контроль становится препятствием и Аля привлечения частного капитала в виде участия инвесторов в приобретении ценных бумаг Аополнительной эмиссии. Аеятельность, направленную на решение, прежде всего, текущих проблем государства, Аостаточно сложно согласовать с намерениями стратегических инвесторов (Kudriashov, 2010).

Так, в апреле в 2009 г. НБУ было принято решение о внесении преАложения Министерству финансов Украины относительно участия государства в рекапитализации ОАО «РодовиА Банк», ОАО «Укргазбанк» и ОАО «АКБ «Киев», по которым уже в июне того же года было принято решение о рекапитализации на общую сумму 9,5 мирА. грн. В результате проведенной рекапитализации этих банков часть государства в РодовиА Банке достигла 99,97\% (2,8 мкрА. грн.), в Укргазбанке - 84,21\% (3,2 мирА. грн.), в банке «Киев»-99,93\% (3,5 мирА. грн.). Всего в течение 2008-2011 гг. на рекапитамизацию частных банков в Украине было использовано 25,8 мирА. грн., что составляло почти 2,3\% ВВП. РодовиА Банк получим 12,3 мирА. грн., Укргазбанк - 9,3 мирА. грн., банк «Киев» - 3,6 мирА. грн. (Mischenko, 2013).

На рис. 1 (National Bank of Ukraine, 2016) видно, что мероприятия государственной подАержки проблемных банков после нестабильной динамики Аали им возможность выйти на Аокризисные показатели. Собственный капитал Ощадбанка бым увеличен почти в 6 раз, капитам Укрэксимбанка постепенно увеличивался с 2008 г., а в 2010 г. вырос в 1,5 раза.

Позитивную Аинамику по величине собственного капитала демонстрирует Укргазбанк, что является рекордным показателем Амя этого банка и высоким показателем среди остальных отечественных банков. РодовиА Банк характеризуются низкими показатемем соотношения уставного капитала и активов, однако миквидность подАерживается государством на приемлемом уровне. В целом показатели ОАО «РодовиА банк» могут считаться приемлемыми в связи с приобретением им статуса санационного банка. Резкую тенАенцию к снижению собственного капитала наблюАаем по результатам деятельности банков за 2015 г. (Амя ОАО «Проминвестбанк» и ОАО «Укрэксимбанк» этот показатемь Ааже Аостиг отрицательного значения). Нынешняя убыточность банковской Аеятельности вызвана, среди прочего, значительным ростом отчислений в резервы через снижение качества кредитных портфелей. Заметим также, что три из восьми исследуемых банков (АО «Банк «Финансы и кредит», ОАО «АКБ «Киев» и ОАО «КБ «НаАра») на Аанный момент ликвидированы.

Крайне актуацьным явмяется вопрос относительно выхода государства из капитала упомянутых банков, поскольку в соответствии с мировой практикой если такие мероприятия и использовались среАи антикризисных Аействий, то Аишь временно. В соответствии с Программой экономических реформ на 2010-2014 гг. важным шагом в процессе обеспечения стабильности банковского сектора была разработка и реализация государственной стратегии относи-

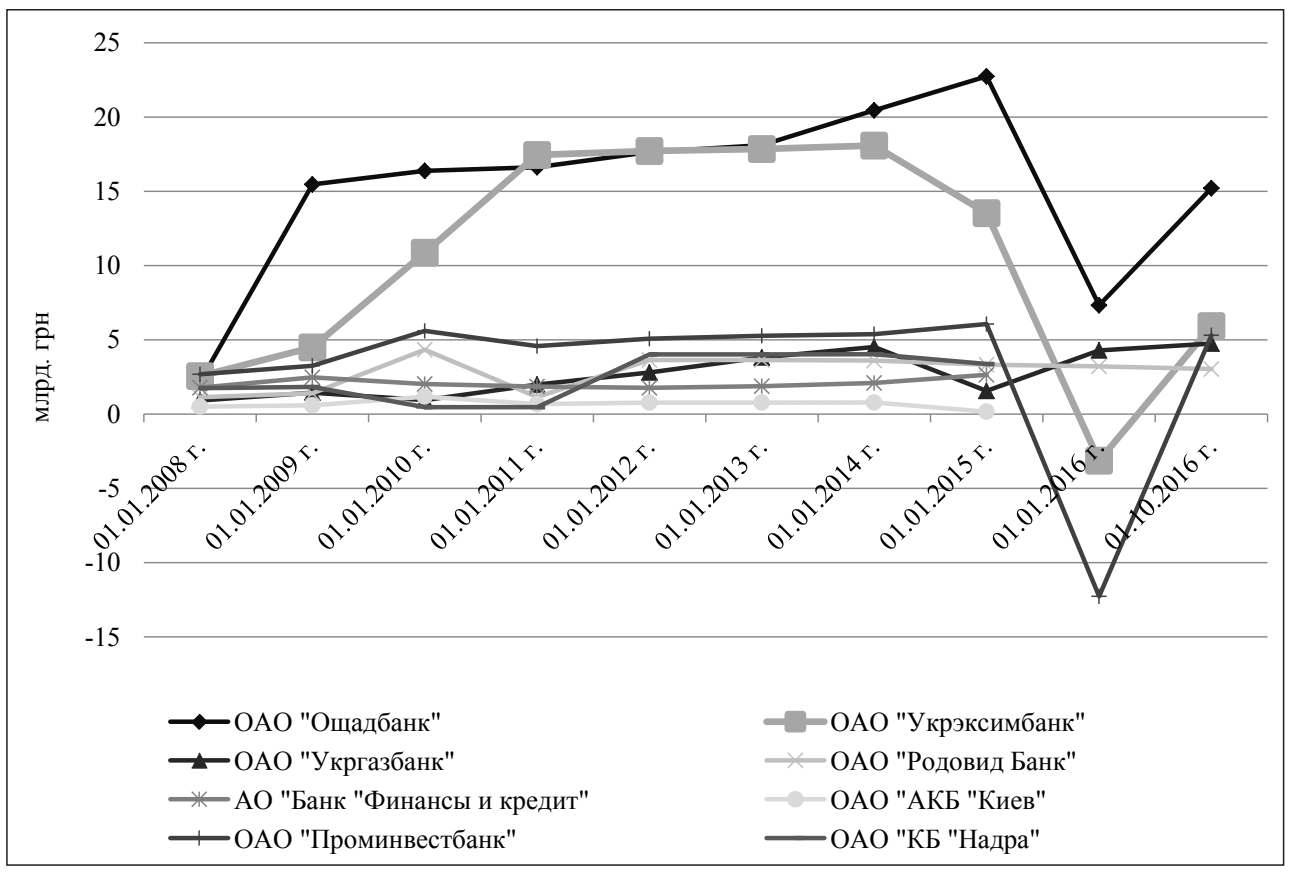

Рис. 1. Аинамика собственного капитала банков, получивших наибольшую помощь за счет бюАжетных среАств, за 01.01.2008-01.10.2016 гг. 
тельно государственных финансовых учреждений и банков, в которых государство стало основным вцаАельцем в результате рекапитализации, что предусматривало приватизацию этих банков.

С цемью обеспечения выхода государства из капитала рекапитализированных ранее банков бым принят Закон Украины «Об особенностях продажи пакетов акций, которые принадмежат государству в уставном капитаме банков, в капитализации которых участвовало государство» от 15.03.2012 г. № 4524 VI. Реализация норм указаного закона позволяет вернуть средства в государственный бюджет Украины, направленных ранее государством на участие в капитализации банков. Но, принимая во внимание общую конъюнктуру банковского рынка и отсутсвие интереса у иностранных инвесторов к украинским банкам, государство не сможет в ближайшей перспективе выгодно реализовать национализированные банки. Аругой путь решения проблем финансовых учрежАений, в капитализации которых участвовало государство, - это аккумулирование среАств этих банков в еАиную структуру, которая бы могла оказывать целевую подАержку проектов правительства. То есть, речь идет о создании нового учреждения ими об объединении активов на базе существующего банка, или усилении роли Украинского банка реконструкции и развития. Вероятные выгоды от созАания такой структуры явмяются весьма весомыми.

Стоит отметить, что в соответствии с Законом Украины «О банках и банковской деятельности» и Законом Украины «О внесении изменений к некоторым законодательным актам Украины относительно предотвращения негативного влияния на стабильность банковской системы» от 04.07.2014 г. №1586 VII минимальний размер уставного капитала на момент государственной регистрации юридического мица, которое намеревается осуществлять банковскую Аеятельность, быи увеличен и на сегодняшний день не может быть меньшим 500 млн. грн. Тем не менее, НБУ планировал инициировать увеличение минимального размера уставного капитала Амя новых банков Ао 750 мин. грн. с 2015 г. (хотя этого в послеАствии не произошио). По словам главы НБУ В. О. Гонтаревой, НБУ планирует реформировать банковскую систему и уже Ао 2020 г. отечественная банковская система будет отвечать европейским стандартам. Национамьный банк страны считает, что в Украине слишком большое комличество банков, а поэтому готовится успешные банки объединять, а проблемные - миквиАировать. По прогнозам национального банка, такие Аействия позволят Ао 2020 г. уменьшить количество банков и повысить концентрацию активов. По оценкам экспертов, сложно сказать, сколько банков останется, но приблизительно до 2020 г. в Украине будет около 120 банков - или на треть меньше, чем сейчас (SEHODNYA, 2014). Также НБУ планирует выделить отАельную группу системно важных банков, Аля кото- рой будут установмены более жесткие требования к нормативам капитала и миквидности, но которые смогут надеяться на более системную и своевременную стабилизационную помощь со стороны НБУ в периоды кризисов. При этом приоритетным механизмом капитализации рассматривают слияние и поглощение банков. В целом, НБУ ставит целью наращивание Аоли иностранного капитала в банковской системе до $50 \%$ и уменьшение роли государства в банковском секторе Ао уровня ниже $10 \%$ к 2020 г. (INSIDER, 2014).

Итак, в 2014 г., Аля преодоления финансово-экономического кризиса в государстве, НБУ при подАержке МВФ осуществиц рекапитализацию отечественных банков на сумму 23,5 мирд. грн., активы или депозиты которых составляют 2\% от общего объема в банковской системе, а в 2015 г. на эти же цели бымо выделено 22,5 мирд. грн. ОАнако и этот вариант механизма рекапитализации, к сожалению, существенно не измениц ситуацию на отечественном банковском рынке (в 2014 г. было миквидировано 19 банков, а в 2015 г. - 41 банк). Таким образом, увеличение уставного капитала при наличии убытков нецемесообразно, поскольку в таких условиях государственные ресурсы, привлеченные с целью рекапитализации, банки направцяют на погашение обязательств (прежде всего валютных, что негативно вмияет на курс гривны), а не на созАание условий Амя обеспечения работы учрежАения. Принимая это во внимание, необходимым явмяется совершенствование Аействующего механизма предотвращения кризисных явлений в банковской системе и выход государства в перспективе из рекапитализированных банков (только Укргазбанк из 3-х национализированных в 2009 г. Аемонстрирует позитивные результаты деятельности). В то же время за этот же период из банков вывели 110 мирА. грн. вкладов (Voronovych, 2014).

Отметим, что Национацьный банк Украины осуществил в 2014 р. стресс-тестирование 35 крупных и крупнейших банковских учрежАений, на которые приходится $82 \%$ активов отечественной банковской системы, в Ава этапа: первый - 15 банков, а второй - 20 банков. По результатам проведенного стресс-тестирования только 5 банков его прошло, в частности Приватбанк, Райффайзен Банк Аваль, Альфа-банк Украина, Сбербанк России и ПУМБ. Сумма необходимой Аокапитализации банков первой группы составляет 56 млрА. грн. (из них 12,5 мирА. грн. Аля Аокапитализации государственных банков, 20,5 мирА. грн. - Аля банков с иностранным капиталом), второй - 10 ммрА. грн. Так, на протяжении 2014 г. и января-феврамя 2015 г. было предоставлено кредитов рефинансирования на сумму 266 млрА. грн., из них (National Bank of Ukraine, 2016): овернайт - 125,4 мирА. грн.; тендерные кредиты и операции РЕПО - 83,3 млрА. грн.; стабилизационные креАиты (поА программы финансового озАоровления и Аля сохранения АиквиАности) - 57,2 мирА. грн. 
24 апремя 2015 г. было проведено стресс-тестирование 20 ведущих банков Украины Аоля которых составила $80 \%$ активов банковского сектора. При этом потребность в докапитализации отсутствоваца у 4 банков, а 5 из оцененных банков ее уже выполнили.

Учитывая нестабильную политическую ситуацию в Украине, можем спрогнозировать углубление банковского кризиса, подтвержАением чего выступают проблемы с миквидностью и банкротство многочисменной группы отечественных банков. Поэтому, на наш взгляА, целесообразным явмяется разработать по результатам стресс-тестирования структурно-логическую схему повышения уровня капитализации банков, которая заключается в выделении 4 категорий банков (финансово стойких и надежных; проблемных; неплатежеспособных; безнадежных (нежизнеспособных) и применить к ним соответственные меры обязательного характера (рис. 2).

Стоит отметить, что прежде чем докапитализировать банки II, III и IV категории, необходимо оценить состояние реального капитала: положительный или отрицательный (все плохие и сомнительные относительно возвращения кредиты должны быть в резервах). Имущество и ценнные бумаги Аолжны быть переоценены по рыночной стоимости с учётом фактических котировок и возможностью государства погашать ценные бумаги.
По Аанным рис. 2 банки II категории необходимо Аокапитализировать за счет среАств собственников на сумму определенного процентного уровня от обязательного капитала (не менее 25\%). НБУ не Аолжен Аопустить никаких «круговых» Аенежных потоков, мишь реальные Аеньги с указанием реальных источников. Те банковские учрежАения, которые не выполнят этого условия в течение трех месяцев, будут вынужАены проходить процессы слияния и поглощения Аругими банками, участников которых опредемяет НБУ. Остальную сумму (не менее $75 \%$ ) необходимой Аокапитализации банков получают за счет конвертации Аепозитов в привилегированные акции этих банковских учрежАений в порядке убывания сумм депозитных среАств. Процентная ставка Аивидендов за привимегированными акциями в долмарах может колебаться в пределах 6-7\%, в гривне - 14-15\%.

ОАновременно с конвертацией банк и владелец ценных бумаг подписывают Аоговора обратного выкупа этих акций по номиналу через 7-10 мет. НБУ Аолжен выступать гарантом выполнения этих соглашений. Кроме этого, НБУ уполномочивает топ-менеАжмент банка или отАельных ключевых менеАжеров осуществить обратный выкуп привимегированных акций к окончанию строка действия обязательств банка. Кроме этого, НБУ Аолжен запретить разделение Аепозитных среАств в течение не

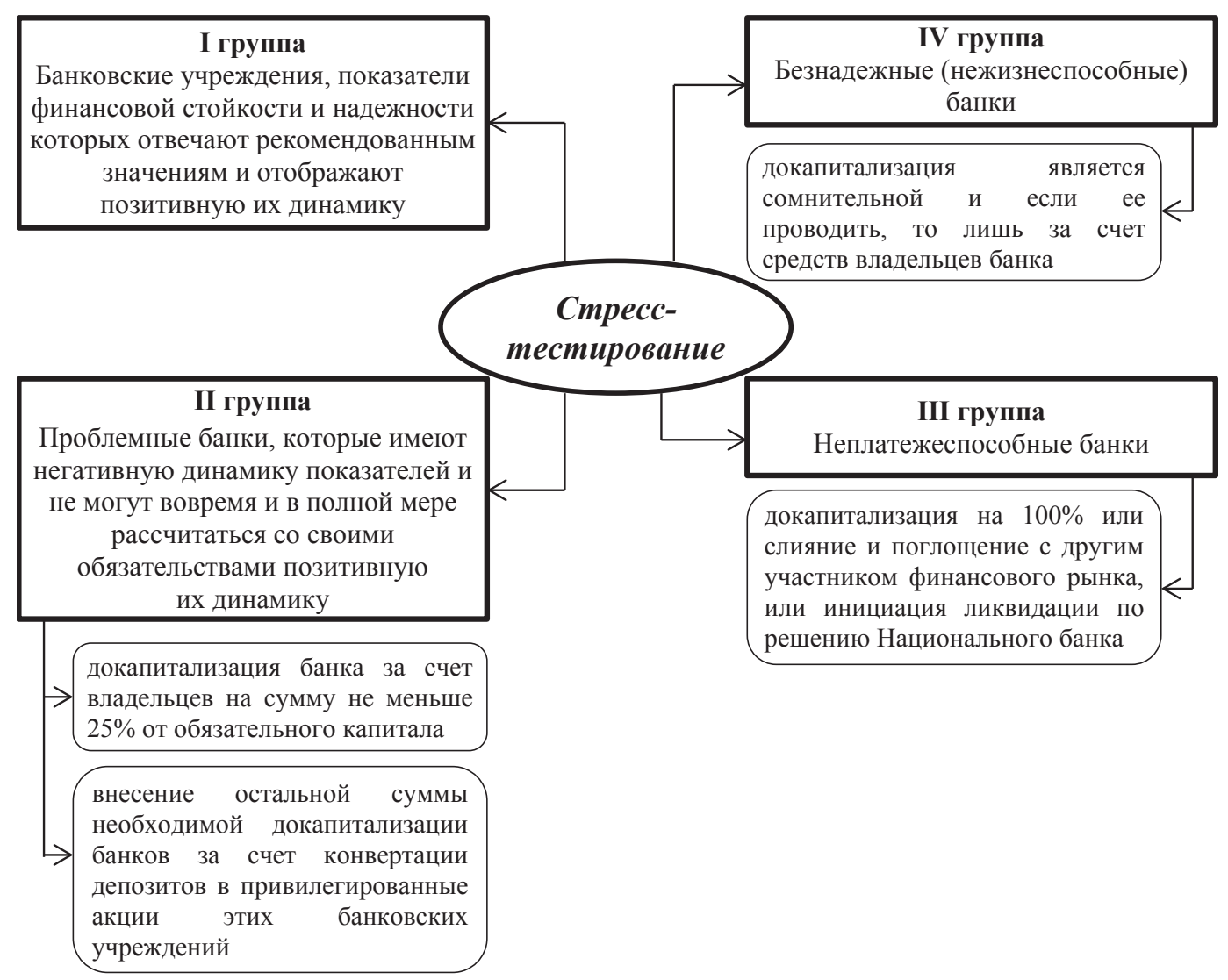

Рис. 2. Структурно-логическая схема повышения уровня капитахизации банков 
менее полугода переА их конвертацией в привилегированные акции банка.

К преимуществам описанного метода Аокапилизации можем отнести: 1) привилегированные акции явАяются капиталом Аля банков; 2) Аля физических миц - это фактически Аолгосрочный Аепозит (без упиаты подоходного налога); 3) привикегированных акции дадут возможность получать дивиденды независимо от результата Аеятельности банка, а в случае банкротства - первоочередную выплату стоимости акций; 4) НБУ не осуществляет эмиссию Аенег и рефинансирование, в результате чего не создаются условия Аля Аевальвации гривни; 5) не предполагается значительный отток среАств из банковских учреждений, а если такое и будет иметь место, то это будет мишь краткосрочный эффект и банки смогут выполнять свои обязательства по миквиАности; 6) фондовый рынок Получит АиквиАность в Аесятки мимииарАов гривен, что Ааст толчок к его цивилизованному развитию, веАь Аоходные привияегированные акции станут реальными миквиАными рыночными ценными бумагами.

Собственники банковских учрежАений III категории, оцененные как неплатежеспособные, Аолжны будут Аокапитализировать их на 100\%, или эти банки буАут проходить процессы слияния и поглощения с Аругими участниками финансового рынка, или буАут миквидированы по решению НБУ. В то же время Аокапитализация коммерческих банков IV группы явмяется рискованной и ее экономическая целесообразность подвергается сомнению.

\section{4. ВывоАЫ}

Проведение рекапитализации проблемных банков при участии государства явАяется оАним из возможных вариантов их озАоровления в условиях эконо- мического кризиса. Во время последнего мирового финансового кризиса правительства развитых стран (и Украины в частности) оказались в ситуации, когАа вливания бюАжетных среАств в финансовые учрежАения стали необходимостью. Были использованы инструменты повышения миквидности, проводился выкуп проблемных активов, предоставмялись гарантии по обязательствам банков, однако наибольший масштаб приобрела рекапитализация, которая в некоторых случаях обрела форму национализации.

Тем не менее, проблемы возвращения депозитов и погашения задолженности переА кредиторами банков целесообразно решать путем рефинансирования и реструктуризации их обязательств, а не рекапитамизации. Применение механизма финансирования рекапитализации проблемных банков при участии государства, который используется в Украине (привмечение ресурсов путем увеличения дефицита госуАарственного бюджета, вложения в уставный капитал активов в форме государственных облигаций и т. п.), приводит к росту государственного Аолга, фискальным Аисбалансам, нарушении стойкости государственных финансов и может превратиться в фактор ускорения инфмяции. На наш взгляА, более целесообразными способами финансирования докапитализации банков явцяются привцечение ресурсов от приватизации государственного имущества и внедрение новых механизмов активизации использования сбережений гражАан, в частности за счет конвертации гривневых и Аоммаровых Аепозитов в привилегированные акции отечественных банков.

В Аальнейших исследованиях автором будут раскрыты теоретико-методические положения функционирования санационного банка Украины как оАного из государственных мероприятий по финансовому оздоровлению отечественных банков.

\section{References}

Deposit Guarantee Fund. (2016). Retrieved November 25, 2016. Retrieved from: http://www.fg.org.ua.

INSIDER. (2014). NBU wants to increase requirements for banks and ban early withdraw deposits. Retrieved from: http://www.theinsider.ua/business/5396aff58703b/.

Kudriashov, V. (2010). Recapitalization problem banks by using government resources. Economy of Ukraine, vol. 1, 37-48.

Mischenko, V. (2013). Capitalization of banking system in Ukraine: Present and Prospects. Journal of the National Bank of Ukraine, vol. 7, 11-17.

National Bank of Ukraine. (2016). Retrieved October 20, 2016. Retrieved from: http://www.bank.gov.ua.

Pan'kiv, Kh. (2012). Capitalization of domestic banks as a basis for investment in the real sector of Ukrainian economy. Formation of Market Economy in Ukraine, 26, 71-78.

SEHODNYA.ua. (2014). What does NBU want to make with Ukrainian banks. Retrieved from: http://ukr.segodnya.ua/ukraine/chto-nbu-hochet-sdelat-s-ukrainskimi-bankami--528502.html.

Tsyhanov, S. (2014). Measures of state support to banking systems in developed countries during the financial crisis. Journal of the National Bank of Ukraine, vol. 1, 12-19.

Voronovych, Z. (2014, October 08). Does Fund guarantees nothing? The High Castle. Retrieved from: http://www.wz.lviv.ua/economics/128843. 


\section{ЮрИЙ РАДЕЛИЦКИЙ, ЮЛИЯ ПОПИВНЯК, ЗОряНа ТЕНЮХ ОСОБЕННОСТИ ГОСУДАРСТВЕННОГО УПРАВЛЕНИЯ КАПИТАЛИЗАЦИЕЙ БАНКОВ В УКРАИНЕ}

Аннотация. Предмет исследования. Предметом статьи являются теоретико-методические и прикладные аспекты государственного управления капитализацией банков в Украине, рассмотрение которых позволяет оценить эффективность рефинансирования и рекапитализации украинских банков, а также сформулировать практические рекомендации относительно повышения уровня их капитализации. Целью является анализ мероприятий государственнойподдержкиотечественнойбанковскойсистемы, атакжепоискдополнительных источников финансирования капитала банков и разработка схемы повышения уровня капитализации банков в условиях социально-экономических трансформаций. Методология. В работе использованы общенаучные методыпознания экономическихявлений ипроцессов в ихнепрерывном развитии ивзаимосвязи:логический анализ, методы научной абстракции, индукции, дедукции, оптимизации, группировки и сравнения, синтеза, а также графический и табличный методы. Результаты. Вопросы государственного регулирования банковской системы в период мирового финансового кризиса исследовали на международном уровне Совет финансовой стабильности, Базельский комитет по банковскому надзору, специалисты Мирового банка и Международного валютного фонда. В связи с относительной новизной этой проблематики лишь небольшое количество исследований посвящено обобщению опыта применения инструментов государственной поддержки банков, поэтому дальнейшее развитие данной темы имеет практическую значимость для совершенствования механизмов возобновления финансовой стойкости и надежности банковской системы Украины. Проанализировав мероприятия государственного регулирования капитализации отечественных банков, начиная с 2009 г., и эффективность выделения бюджетных средств на проведение рефинансирования и рекапитализации банковских учреждений в Украине (в том числе и в условиях кризиса), выяснено, что эти механизмы, к сожалению, существенно не изменили ситуацию на банковском рынке. Учитывая нестабильную политическую ситуацию в Украине и ее пребывание в военном конфликте с Россией, который влияет на рост инфляции, обесценения национальной валюты и панический отток депозитных вкладов, спрогнозировано углубление банковского кризиса, подтверждением чего названы проблемы с ликвидностью и банкротство многочисленной группы отечественных банков. Поэтому целесообразным является разработка структурнологической схемы повышения уровня капитализации банков, которая заключается в выделении за результатами стресс-тестирования 4 категорий банков и применение к ним мероприятий обязательной докапитализации или процессов слияния и поглощения: 1) финансово стойких и надежных; 2) проблемных; 3) неплатежеспособных; 4) безнадежных (нежизнеспособных) банков. Выводы. Проведение рекапитализации проблемных банков при участии государства является одним из возможных вариантов их оздоровления в условиях экономического кризиса. Тем не менее, проблемы возвращения депозитов и погашения задолженности целесообразно решать путем рефинансирования и реструктуризации их обязательств, а не рекапитализации. На взгляд автора, более целесообразными способами финансирования докапитализации банков являются привлечение ресурсов от приватизации государственного имущества и внедрение новых механизмов активизации использования сбережений граждан, в частности за счет конвертации гривневых и долларовых депозитов юридических и физических лиц в привилегированные акции отечественных банков. 